\title{
"This is the Way, Walk Ye in It": Rebuilding the Christian Science Movement
}

\author{
Rolf Swensen \\ City University of New York, New York, U.S.A
}

\begin{abstract}
During the past 10 years, the Christian Science movement has discarded large expensive public relations efforts to concentrate on the writings of the founder, Mary Baker Eddy (1821-1910) and the central role of healing. This paper examines this seismic shift, delves into the reasons for the change of strategy, and suggests a renewed interest in the movement's history and other forms of outreach to help revive a movement that has been in decline just after World War II. Resources for this study are the monthly Christian Science Journal, resources of the Mary Baker Eddy Library in Boston, and the writer's own research and publications on the history of Christian Science.
\end{abstract}

Keywords: Christian Science, Metaphysics, Healing, Sects

\section{Introduction}

In early December 2004, a watershed event occurred at a meeting of the five-member Christian Science Board of Directors of The Mother Church, The First Church of Christ, Scientist, in Boston, Massachusetts. Virginia Harris, the dynamic, progressive, longtime chair of the board, resigned her position. In her 12-year tenure as chair, Harris had taken the movement from closed doors to the world through the opening of the Mary Baker Eddy Library for the Betterment of Humanity in 2002 and had opened a dialog on spiritual healing with other faiths and the medical community (Church Board Announces Changes, 2004). The significance of the Board change has not been previously reported. It is correctly believing that the Christian Science movement had strayed from its original mission of healing and that The Mother Church had engaged in too many expensive projects, the post-Harris board embarked on a venture to "rebuild" with fiscal restraint, a formerly vibrant American church that had been in serious decline since World War II. As Director Margaret Rogers later remarked, "There was this feeling that we had gone into a marketing phase and we kind of lost our sense of the purity of our healing mission” (Paulson, 2009). There are indications that a significant expanded form of outreach is currently being considered. This paper investigates the profound change in the direction of the Christian Science movement since 2004, illustrates how The Mother Church's restraining hand after 1908 resulted in unintended negative long range effects that required correction, and advocates a revised course of action that would assist moving this distinctive American church from the 19th into the 21st century.

Mary Baker Eddy, discoverer and founder of Christian Science, published her path breaking textbook, Science and Health, in 1875. In this book, she maintained that since God created man "in his own image”, man

Rolf Swensen, Ph.D. , Acting Chief Librarian, Queens College, City University of New York.

Correspondence concerning this article should be addressed to 64 Gardiner St., Darien, CT. Email: rolf.swensen@qc.cuny.edu/rolfswensen@aol.com. 
is therefore spiritual and perfect. This understanding was the basis for Eddy's healing of sin and disease. Within a few years, Christian Science, which was spread mainly by female healers called practitioners, blossomed with increasing rapidity across the country (Gottschalk, 1973), whose three-volume biography of Eddy set the standard for all future scholarship, observed that Eddy's "work has been to discover and teach the structure of law implicit in demonstration of man's true being”. For biographer Stephen Gottschalk(1973), Eddy saw Christian Science as a "demonstrable understanding of spiritual power at work in human affairs".

\section{The Post-2004 Renewal of the Christian Science Movement}

About 18 months after the Board change and just before the June 2006 Annual Meeting, Nathan Talbot, clerk of The Mother Church and a member of the Board of Directors, wrote an open, seminal letter to Christian Scientists, in which he observed, "There is significant evidence that the Christian Science movement is underestimating this revelation and its meaning to humanity”(Talbot,2006). As a result of visiting many congregations around the world and conducting numerous regional meetings, the Directors had concluded that many members were "underestimating this revelation", its central role of healing, and the need to "find in her writings” (Talbot, 2006).

Therefore, in the past nine years, there has been an increasing emphasis on Eddy, as well as on healing. During 2011, there was a series of articles entitled “Lives Inspired by Mary Baker Eddy's Example”, including pieces by Stephen R. Howard, Judy Huenneke, Thomas Johnsen, Alison Hughes, and Wanda Richard. In this series, Allison W. Phinney remarked, "Her book Science and Health and her life had infused me with a purpose that I would otherwise never have known”(Phinney, 2011). One participant at a Portland, Oregon youth conference asked the monthly church organ, the Christian Science Journal, "Do you think Christian Science puts too much emphasis on the Mary Baker Eddy relationship and her view on Church versus a one-on-one relationship with God". In his answer, Paul Grimes spoke for the movement when he exclaimed, "What she leads us to is God, one Mind”(Grimes, 2011).

Healing is the order of the day. Articles on early workers, Eddy students, and early church history, which blossomed after the opening of the Mary Baker Eddy Library in 2002, have gradually disappeared from the Journal, which has resumed its commitment to pure metaphysics and its former staid appearance. As the Directors have written, "Quite simply, the standard by which our Church is measured is whether or not healing is taking place”(Church Renewal, 2010, p. 14). Many Christian Scientists believe that one cannot join their fold unless one first has a healing. Others, in part following Eddy's lead, maintain that one cannot be a Christian Scientist unless one is an active healer. When this writer reminded a local church pillar that the Apostle Paul exclaimed, "And he gave some, apostles; and some prophets; and some, pastors and teachers"(Renewal, 2010, p. 15), the stinging retort was that Christ Jesus and Eddy said that one had to be a healer.

For the past several years, there has been an outreach of The Mother Church called "Church Alive", manifested in a website, which sponsors various call-in workshops, and three-day in-person regional conferences. In one recent posting entitled "Healing: At the Center of Everything", author Ken Girard explained that healing is the "most significant aspect of Christian Science that makes it unique..." (Girard, 1988). Christine Driessen, lecturer and teacher of Christian Science, has participated in dozens of interfaith workshops on prayer and healing, usually sponsored by branch churches (Driessen, 2011). As opposed to the more staid Journal, the weekly Christian Science Sentinel, contains news, interviews, features, photos, and advertising, with a focus on healing, 
One should make a case that social work is a form of healing, or at least could facilitate significant healing of individual and societal ills. The issue of social work, hitherto almost absent from the Christian Science movement, has been down played, although it is present on an individual basis and there is some indication that the Board of Directors may endorse or encourage it. During the 1970s, Lenore D. Hanks, a member of the Board of Directors, told this writer that one third of the movement wanted to branch out into social work. The Directors commended the late Second Reader of The Mother Church, Suzanna Cowin in 2006, because she "actively participated in Boston's diverse ethnic communities, especially the Hispanic neighborhoods. As a result of her work, many new and lasting relationships were formed with The Mother Church”. More recently, Robin Hoagland, a new member of the Board of Directors, "volunteered her time to post-Katrina clean-up efforts, and helped with outdoor worship services for the homeless". Yet more common is an article decrying charitable work as the evil influence of the "serpent" deflecting one from being a "good Christian Science healer”(Wolf, 2010, p. 30).When someone at the Church Alive Summit at Third Church of Christ, Scientist, New York, in March 2012 asked the Board of Directors via Skype about branch churches engaging in community outreach, the Directors poured water on the idea.

An integral part of the church's new persona follows Eddy's dictum of "wisdom, economy, and brotherly love”(Eddy, 1936, p. 77). Ned Odegaard, former Treasurer of The Mother Church, observed in a 2010 article in the Christian Science Journal that the church had put itself on a diet of fiscal restraint. According to Odegaard,

\footnotetext{
"About six years ago — precisely when Harris resigned, the Board at that time felt that it urgently needed to reduce spending, and in a one-year period cut spending in half, to around \$100 million. It has stayed pretty close to that level”.
}

For example, opening the Mary Baker Eddy Library in 2002, worthwhile as it is, did cost a lot of money, causing subsequent library retrenchment. At the recent 2013 Annual Meeting, Director Michael Pabst, recalling the June 2003 Annual Meeting in Berlin, remarked that this type of forum was too expensive and that the current Web broadcast was far less costly and gave members around the world the chance to be part of the action (Dunbar, 2013).

The present leadership seems to be relatively unconcerned about the work of most early Christian Scientists, preferring to call attention to the missteps of a few early leaders, such as Eddy student Ursula Gestefeld. Speaking of the movement in the late 1880s, Director Mary Trammell wrote, "They loved the healings and prosperity that Christian Science brought them, but too often shrank from the spiritual commitment they needed to become selfless healers and to share the Comforter with humanity" (Trammel, 2010, p. 29). While there is much truth to this observation, it is wrong to apply it across the board to the early followers, who have largely been forgotten.

Indicative of the lack of historical appreciation is the proposition that it may be more spiritual to meet in a storefront with a few dozen people than try to refill a magnificent old edifice and, in so doing, fail to honor the pioneers who painstakingly built it. First Church, Seattle stated that "we really had spiritually outgrown our old 'cathedral'. Dark and cavernous, formal and cold, the building did not reflect the new spiritual openness we were seeking” (Clay, 2009, p. 13). This reasoning suggests an acquiescence of failure and a slap in the face of their predecessors - in this case Allan Armstrong and cohorts in Seattle, without whose work there would be no movement there today. At the Annual Meeting of The Mother Church, held on June 2, 2013, a member from Capetown, South Africa reported via video that they were striving for a "spiritual church without walls", so they sold their financially burdensome large old edifice that "belonged to the members of the past". The early 
workers, including the unheralded rank and file, have much to convey to the present membership besides bygone healings.

In fact, Eddy herself encouraged church building, albeit with some reservations. In 1896 she wrote to Edward Kimball , a leading Chicago Christian Scientist, "But I know that it is the purpose of Divine Love for Christian Scientists to own a church edifice of their own in Chicago whenever this can be accomplished for the greatest good of the greatest number "(Eddy, 1896). She rejoiced late in 1903 at the "beautiful edifice" going up in her city of Concord, New Hampshire, yet she had recently charged that the 2200-seat "fashionable church edifice” that Augusta E. Stetson's First Church in New York has just opened masked that branch's tendency to "serve both God and mammon". Christian Scientists and others would benefit from reading Ivey.

Why not apply the currently popular anti-Edifice complex and anti-historical strictures to The Mother Church complex, including the Romanesque original Mother Church edifice (1894) and the adjacent soaring domed Byzantine/Italian Renaissance Extension (1906). In part, this is impossible because of Eddy's Church Manual provisions and also because the church edifices have become an inspirational symbol to the movement (Eddy, 1936, p.103). The present Directors have wisely rented out much of the impressive Church Center space to Northeastern University and other organizations and have sold several of Eddy's homes to the Longyear Museum, located in suburban Chestnut Hill, Massachusetts, in an effort to concentrate on healing outreach.

\section{Changes in the Movement, 1908-1910, and their Long-range Consequences}

The problems confronting the Church of Christ, Scientists are far more complex than overspending and relative lack of healing. To understand the new direction of the movement, it is necessary to examine some of the profound changes that Eddy and others instituted in 1908 and how an unenlightened implementation of that strategy eventually hamstrung the movement, resulting in post-World War II decline, lethargy, and less healing outreach. Buttressing all of Eddy's efforts was her long-standing crusade to persuade her church members to concentrate on healing, to counteract the increasing worldliness and success of the movement. Aware of and grateful for the impressive growth of her movement, Eddy observed to the Christian Science Board of Directors, "Our prosperity in the field is a marvel, but we need better healers" (Eddy,1903). When Kimball asked Eddy what would happen to the movement if she should pass on, she replied "It would degenerate into material prosperity”.(Eddy,1903) This apprehension lay behind many of her later directives, including her admonitions to concentrate on healing.

One first has to define what she meant by healing. Eddy(1903) clearly maintained in Science and Health that the "mission of Christian Science now, as in the time of its earlier demonstration [Jesus' healings], is not primarily one of physical healing”.(p. 150) Rather, physical healing is to "attest the reality of the higher mission of the Christ-power to take away the sins of the world”(Eddy, 1934, p.150). Yet Eddy's letters constantly attested to her strong desire for her followers to heal, expressed in words that appear to imply the importance of physical healing”. As she wrote to her cousin Alfred E. Baker, "The Cause [sic] needs healers a million times more than teachers”.(Eddy,1903, p. 150)

It may come as a surprise to Christian Scientists and others that Eddy was not the only one shaping her church. Early in 1908, faced with lawsuits brought about by intemperate remarks and actions of Christian Scientists, Alfred A. Farlow, Manager of the Committees on Publication of The Mother Church, sent a letter on February 25, 1908 to all Committees on Publication throughout the world. "The evil one is lying in wait for us at every point and it certainly behooves us to be wise”. This advice, part of a concerted campaign of protection, 
meant watching any remarks on Christian Science in public, including in church. Outreach was being constrained and was unmistakably and forcefully mirrored in the church periodicals in the following months (Swensen, 2004, p. 35).

Eddy was also engaged in an allied, long-running campaign to curtail the worship and practice of “personality”, or human traits (Swensen, 2004, p. 41-46). As early as 1887, she advised, "Stop trying so hard, make less of personality..." (Eddy, 1887). A few years later, she wrote, "There is no personality, and this is more important to know than there is no disease”(Eddy,1893). Those powerful words conveyed Eddy's growing conviction that some of students and followers were fastening too much on her personality and that of fellow workers in the field. In 1906, she admonished the troublesome Stetson, "I am praying and striving to escape from my own personality, while fools are following it and hounding my person only to hoodwink themselves and fetter my faith and spiritual understanding”.(Eddy,1906) Stetson may have caught the strong inference that she herself was among the chief culprits. Writing on behalf of Eddy, her secretary Irving C. Tomlinson wrote to Sarah Pike Conger, wife of the former American Minister in Beijing ,"We cannot worship personality and divine Principle at the same time”, she urged (Eddy, 1907).

\section{Brief Case Studies of Two Church Manual By-Laws}

The Church of Christ, Scientist, is governed by Eddy's Church Manual, which first appeared in the 1890s and went through many revisions until her passing in 1910 (Eddy, 1936). Many of the by-laws were intended to restrain overzealous and sometimes power-hungry followers, such as Stetson and Gestefeld (Christian Science Publishing Society,1979). While the Manual has helped hold the movement together, it has also served as a drag, in part because it cannot be amended to conform to new conditions and also because of narrow interpretations over many decades by the Board of Directors. Rather than unquestioningly following every word in the Manual, Christian Scientists should see that certain by-laws were written for specific situations that no longer exist. Two examples of by-laws hamper the movement.

\section{“Numbering the People”}

Early in 1908, faced with a burgeoning CS movement and the breezy, sometimes arrogant behavior of members, Eddy added Article VIII, Section 28: "Numbering the People”. The bylaw reads, "According to the Scriptures they shall turn away from personality and numbering the people”. That is, CS churches should no longer publically report their membership figures. Eddy had written Archibald McLellan, editor of the Christian Science Journal and Sentinel, on April 13, 1908, that since bragging of Scientists about church growth, which might prove "offensive" to other religious denominations, the church periodicals were to publish only Christian Science statistics (Eddy, 1908). Since she was also clearly concerned that her flock was playing the mere numbers game, she had her secretary, Adam Dickey, send a letter to her public spokesman two months later, urging the church not to release any more membership statistics. "Our Leader says statements of this sort arouse the enemy and provoke opposition and we should conform to the scriptures, 'Boast not thyself'”.

This was logical in 1908 and for several decades thereafter, when her church was either the fastest or second-fastest growing religion in the United States, but for a declining church desperately requiring new members, narrow interpretation of this bylaw has led to lethargy. As Michael Pabst(2013), a current member of the Christian Science Board of Directors, recently wrote, "Strength is not in numbers...".(p.51) This strongly 
implies that Christian Scientists should not be concerned about their empty, closing churches, but only about healing. Director Nathan Talbot(2012) discusses the bylaw, notes that the church doesn't need to "publish numbers to get the message when a lot of church pews are empty", and poses a question to members: "Are you up to helping others in need?” ( p. 26-27)

Was it Eddy's intention that her followers not care about attracting members? Did she not ask Kimball, Lathrop and others to erect spacious edifices, to accommodate ever increasing worshippers and achieve a more public presence (Swensen, 2010, p. 6) Yet Eddy(1934) did write, "You may know when first Truth leads by the fewness and faithfulness of its followers" (p. 225), but to apply this observation to the present truncated state of the movement is to take Eddy's thoughts out of context.

Since churches were not to dwell on the numbers of members, after 1908 people began to stop valuing the history and community outreach of their organizations. For instance, in the early days of First Church, Atlanta, Stetson and Eddy student Sue Harper Mims (1832-1913) and others compiled scrapbooks, photographs, and other evidences of church growth. All of these records highlighted the work of Mims and others by name. Likewise, in First Church, Portland, Oregon, Blanche Hersey Hogue (1868-1953) made certain that the church had extensive historical files, including many photographs, notes and letters of Hogue, cancelled checks from the 1890s, and annual letter boxes - some of which contained detailed information on the construction of the 1200 — seat church edifice in 1907-1911. As this writer noted, "All told, the vault in First Church of Christ, Scientist, Portland, provides a truly intimate picture of the early Oregon Christian Scientists”(Swensen, 1973, p.16). Most of these files were destroyed when the church disbanded, although the membership roll is at The Mother Church. First Church, New York City, the fiefdom of the talented but autocratic Stetson until her excommunication from The Mother Church in 1909, contained about 75 linear feet of every type of record, including Stetson's musical compositions and poems, and a 32-page history of the church. These records exist at The Mother Church.

Local church histories illustrate the lessening of concern for branch church organization. First Church, San Diego published a detailed church history in 1907 (Swensen, 2004, p. 48), listing the names of current members. Yet six years later the same branch church produced a thumbnail historical sketch, which should be termed "wooden" and uninformative, since the Christian Science Journal now encouraged histories that omitted all names and all specifics except the dates when the church was organized and its edifice opened. This sketch was part of a series of brief branch church histories appearing in the Journal in the 1910s and 1920s.

Thus, after Mrs. Eddy's passing, branch churches generally stopped compiling or collecting most historical records except minute and roll books, because church was supposed to be only the "Structure of Truth and Love" (Eddy, 1934, p. 583). Personality was taboo, concern for numbers morphed into indifference about their own church organization, which would have a profound impact on the movement. It would be interesting to find out if Eddy ever wrote one word that discouraged church growth or that numbers were indeed unimportant. Her words are construed to mean that members were not to be concerned about church outreach or growth, but only about their own healings and outreach only through healing.

If the aim is to rebuild the movement from its present rump, then one must make people feel welcome, including those who have fallen away. In an interview in December 2013 Christian Science Journal, former Director Mary Trammel (2013) quotes an 1886 letter from Eddy, in which she says, "Those who are not helping this church will at length lose their power as healers”( p.12). The letter applies to a situation peculiar to the period and illustrates the pitfalls of taking Eddy's letters and other guidelines out of context. Instead of 
blaming people for leaving the movement and predicting their spiritual impotence, one should take a cue from the Roman Catholic strategy of the early 1980s of "Come Home", as well as the efforts of the present Pope Francis I to be more inclusive.

\section{“A Reader not a Leader”}

How might "personality” apply to church readers? One bylaw entitled "A Reader not a Leader” (Eddy, 1936, p. 33) has also had a profound impact on the movement. Thinking that they were following Eddy's wishes, for more than a century, readers of branch churches have shied away from showing leadership. Until recently, most readers did not even emerge to greet the congregation after the service. Faced with some monumental egos, Eddy had gradually changed the role of reader and limited their terms to three years. “However, as 'A Reader not a Leader' shows us, this role was gradually reshaped into one that centered on providing support, not in controlling a church” (Mary Baker Eddy Library, 2009).

Did Eddy intend that readers shy away from proper leadership and initiative? Clearly, since she also placed church discipline in the hands of the first reader, she "saw the First Reader's position as a highly important one in a branch church of Christ, Scientist, and in the Christian Science movement as a whole”. That is, Eddy saw the First Reader as showing a leadership role, while not dominating a church as its "Leader". Early in 1910, with Eddy's blessings former Populist Party leader Virgil O. Strickler, First Reader of the excommunicated Stetson's First Church of Christ, Scientist in New York, presided over a tumultuous session to elect new church trustees not beholding to Stetson (Swensen, 2008, p. 86). Christian Scientists, including readers, must not be afraid to show initiative and leadership and must not be wedded to a slavish interpretation of the Church Manual.

It is encouraging that the present Board now urges a freer interpretation of the Manual. However, Eddy made it abundantly clear to the Board how important her Manual was and is: "The present and future prosperity of the Cause of Christian Science is largely due to the [Manual] By-Laws and government of 'The First Church of Christ Scientist' in Boston” (Eddy, 1903). The challenge is how to adapt Eddy's rules to changed circumstances in the 21st century.

\section{Concentration of Power in the Mother Church}

Any consideration of the Christian Science movement must deal with the evolution of the Board of Directors. Even during the latter years of Eddy's life, the Board steadily increased its authority over the movement, while many individuals and branches looked to Boston for answers to questions. According to Mike Davis of the Eddy Library, the Mother Church was "only too willing" to give advice; this complemented the dramatic lessons the movement learned from the 1909 ouster of Augusta E. Stetson and others, to toe the Boston line.

Hundreds of letters written by William B. Johnson, longtime Mother Church Clerk and Board member, attest to the constant questions that branch churches asked about how to run their churches. Sometimes he would give advice, usually after checking with Eddy, such as the time he quashed the idea of four Chicago branches to run an adult Sunday School (Johnson, 1904). It would be useful to examine Johnson's voluminous letters press books of William B. Johnson, but these have not been cleared for scholars to use. The Mother Church increased its authority through the Manual, branches seeking advice, and strong-arm tactics aimed at eliminating "personality". 
The most divisive event in the history of the Christian Science movement was the lawsuit that the “increasingly contentious Western-oriented Board of Trustees" of the Christian Science Publishing Society brought against the Christian Science Board of Directors, 1919-1922. After the Directors won, they gradually built "almost unquestioned control over the movement". The effect was profound. "Policies of reticence that had been logical from 1908-1910 and the years immediately following, became rigidly codified by uninspired bureaucrats, ultimately hamstringing the movement and its members and blunting most of the active healing outreach that Eddy desired and Farlow assumed would happen”. Without commenting on the litigation and concentration of power in Boston, Stephen Gottschalk notes a "certain cooling and descent into respectability among Christian Scientists in the decades following Eddy’s death” (Gottschalk, 2006, p. 409). These statements require further research.

Despite relaxing of Boston's powers, some of the authoritarian spirit still lingers. One of the organizers of the 2012 Church Alive Summit in New York commented to this writer that he was disappointed that the sessions were the "usual top-down” event. Neither Eddy nor the Directors have fully trusted the membership to evangelize the faith.

Construction of the Christian Science Center in the late 1960s and early 1970s portended a new age for a movement that had been declining since the end of World War II. According to New York Times, the center, which unofficially opened in June 1973, constituted the "most visible sign of the new self-confidence" of the church. Initially planned to cost $\$ 8$ million, the E.M. Pei designed complex, with a 600-foot pool, 27-story administration tower, and separate Sunday School building, which ended up nearly bankrupting the church with a price tag of over $\$ 80$ million. In fact, even though the center unofficially opened during on June 4, 1973 in the Annual Meeting, one of the speakers noted that the church had been so strapped that officials had sometimes wondered if they could avoid financial meltdown by closing time each business day. These remarks never made it into the official reports for the meeting published in the Christian Science Journal (Annual Meeting , 1973).

Apparently unmentioned in the media, church records, or private correspondence was the biggest drawback of the Church Center: the artificiality of launching the center in 1966 - the centennial of Eddy's

“discovery of Christian Science — and its official opening in 1975, to coincide with the one hundredth anniversary of the first publication of Science and Health. The center was supposed to spur growth, but Director J. Thomas Black diplomatically noted that "it just didn't work out that way".

Although physically impressive, awarded landmark status, and a great community asset, the Center should only have been built as a result of church growth, rather than expecting the center itself to foster such growth.

By 1969, as the center was moving forward, The Mother Church realized that the movement had become too ingrown. In a seminal letter to church members, Charles Louis Reilly outlined the problem and the solution. Asking members, "What are we, as Christian Scientists, doing about the world's problems?" "The answer plainly is: Not enough". Reilly urged greater outreach. "Despite the effectiveness of all that The Mother Church is doing ... the message of Christian Science, even in this mass communication age, still travels essentially one to one". That is , members were now to show initiative, but had been told for decades to "protect" their faith. Such outreach that Reilly advised would cost the church nothing financially, as opposed to other expensive schemes that did not utilize the membership. Perhaps the Reilly missal was intended to buttress the Church Center, but there was insufficient follow- up to that benchmark letter (Swensen, 2004, p. 52-53).

The church's bold but brief foray in the late 1980s and early 1990s into television journalism and a new 
monthly news magazine, both called World Monitor - which required gutting the daily Christian Science Monitor, ignited a "firestorm of protest" and ended in a huge financial loss. This writer noted that the World Monitor failed "in part because of insufficient financial resources and also because it did not enlist the efforts of individual Christian Scientists”. That is, the church and its members had quickly forgotten Reilly's strong suggestions. Some writers have noted the decline of Christian Science.

Through the efforts of Virginia Harris, the Mother Church opened the Mary Baker Eddy Library for the Betterment of Humanity in 2002, which made available for scholars great hoards of previously sequestered Eddy letters and church records. According to the Christian Century, "The [Eddy] library represents the church's boldest attempt to reach the wider public since a Monitor Channel television venture flopped to the tune of a $\$ 300$ million loss in the 1990s”. Though it severely drained church finances, the library has placed a public face on a hitherto overly protective church and might even attract some people to the fold. Even this enlightened effort still relied on The Mother Church to spearhead outreach, although the almost-simultaneous “Good Samaritan” effort of 2003-2004 did resemble Reilly’s 1969 appeal for individual efforts (Swensen, 2004, p. 56-57).

\section{Researching the History of the Movement, an Essential Ingredient in Rebuilding the Church}

One great resource at the disposal of the church is the lessons revealed by researching the history of the movement, found at the Eddy Library and local church records. The Mother Church and the Christian Science movement should heed Eddy's urgent request made in 1888: "Christian Science and Christian Scientists will, must, have a history...” (Eddy, 1888, p.106) All the biographies of Eddy, including the excellent ones by Peel and Gill, do not constitute a history of the movement. However, one must be careful about defining Eddy's use of the term "history". Writing to the superintendent of the Christian Science Dispensary Association, Eddy advised, "Stand firm on the history of Christian Science". Yet her secretary Irving Tomlinson approved church spokesman Alfred Farlow's plans for a history of Christian Science that would necessarily involve biographical treatment of Eddy (Tomlinson, 1903). Christian Scientists mistakenly regard biographies of Eddy as a history of the movement, but far more transpired in the early development of the church that did not directly revolve around Eddy.

In 1969, at the beginning of his decades-long quest for Christian Science history, this writer offered the following observation:

Christian Scientists themselves, oddly, have seen little value in the preservation and chronicling of more than a skeletal outline of their national and local history. Although the [sic] Mother Church in Boston has painstakingly collected all available data on the life of Mary Baker Eddy, discoverer and founder of Christian Science, authentic and useful information on the growth of her church and its leaders is widely scattered or nonexistent. In addition, certain denominational rules and mores have hitherto precluded the use of church records for scholarly purposes by Scientists and non-Scientists alike.

This statement should be qualified. Prior to 1908, the Journal and Sentinel reprinted many sometimes detailed accounts about branch churches. For more than a decade after 1910, there were regular snippet histories of branches in the Christian Science Journal, but these offered no reliable information, other than the dates when the study of Christian Science began in their locality and the date their edifice opened. There were calls for local churches to send historical information about themselves to The Mother Church in both 1917 and 
1930, but these efforts resulted in minimal holdings for most branch churches. Extensive records for branch churches mainly came later from some disbanded entities, such as First and Second Churches, New York City and First Church, Salt Lake City, recently added to the Mary Baker Eddy Library.

The opening of the Mary Baker Eddy Library in 2002 seemed to enhance the picture for investigation of the history of the movement. As this writer was launching his present series of articles, he wrote:

It is time that this focus should embrace leaders besides Mary Baker Eddy and encompass the forgotten rank and file. The opening of the Mary Baker Eddy Library for the Betterment of Humanity, at The Mother Church in Boston, on September 29, 2002, tends better times for historians of Christian Science. As The Mother Church continues to declassify thousands of letters and church records for inclusion in the library and more local, or branch, churches shed their ninety-five-year-old collective secrecy, scholars will be able to study in detail the motivation, social composition, challenges, and practices of this controversial American religion. (Swensen, 2003, p. 230-231)

The Eddy Library has indeed opened vast resources of church records for scholarly endeavor, but, as this present study demonstrates, the focus of attention in the movement has shifted since 2004 to zero in even more intensely on Eddy.

The movement must value its own history as inspiring, challenging, and loaded with valuable lessons, even after 1910. This would include the rank and file in Eddy's day, as well as all Scientists throughout the history of the movement. Thus, the hundreds of thousands who gave their all will be rescued from oblivion. One useful undertaking would be a dramatic article on the 30,000 members attending the six dedication services of 5,000-seat "Extension" of The Mother Church in June 1906, beginning with organist Albert F. Conant's first chords of Gustave Merkel's Fantasie in E Minor on the new four-manual 72-stop Hook and Hastings organ (Communion Service and Dedication, 1906). Another suggestion is to encourage a series of scholarly articles in the church periodicals on post-1910 leaders of the movement, such as Blanche Hersey Hogue, John Randall Dunn, John Tutt, Julia Johnston, other CSBs and lecturers from the US and abroad, etc. It would be useful to launch an investigation of the impact of Christian Science on other religions.

\section{Other Ways to Reinvigorate the Christian Science Movement}

It is wise that the Church of Christ, Scientist has shed its "edifice complex", much of the imperial Mother Church and its virtual stranglehold, and returned to the basics that built the movement. However, to recapture the dynamism that was responsible for the meteoric rise of Christian Science, the faith should consider other changes.

The Directors and the rank and file should understand that the "human organization" is essential to rebuilding the movement. Pure metaphysics and healing must be accompanied by other forms of outreach, coupled with far more active fellowship, reminiscent of the cooperative attitude of the early Christian Church as described in the book of Acts, as well as aspects of these practices in the early days of the Christian Science movement. This was when the Scientists referred to each other as brother and sister, as is the norm in some other faiths.

It appears that the Board has been trying to take the movement back to its healing origins in the 1870s, while retaining many of the strictures, rules, and by-laws enacted by Eddy for her surging church up to 1910 . The movement must progress beyond where Eddy left it, rather than trying to carry out to the letter every word she wrote throughout her long life. The church periodicals now almost exclusively feature articles that refer to Eddy or occasionally Jesus and the Bible. What about other religious leaders throughout history? 
The movement must discard the notion that only Eddy can show leadership. Individual initiative, leadership and new ideas are solely needed. Augusta E. Stetson, Ursula Gestefeld, and Josephine E. Woodbury, all thorns in the movement's side, profoundly influenced Eddy, but passed from the movement more than one century ago.

For the Christian Science Journal to live up to its designation as a journal, there must be more than an occasional quotation from and citation of previous church periodical articles. The three recent editions of Anthology of Classic Articles from church periodicals are a welcome start in the right direction.

Especially since Eddy left no provision for amendments to her Church Manual, there should be a more elastic interpretation of by-laws, particularly those that apply to non-relevant situations in the distant past. It is true that the present Board refreshingly "encourages individuals and churches to go to the Manual and come to their own inspired and prayerful conclusions...” (Estes, 2013)

There must be a concerted effort to encourage community outreach beyond Manual-inspired activities, to emerge from the church cocoon and regain the momentum lost after 1910, but only evidenced after World War II. One simple but positive example is provided by First Church of Christ, Scientist, Port Townsend, Washington, which "gave a loaf [of zucchini bread], along with the Thanksgiving Bible Lesson and an invitation to our Thanksgiving service, to each family staying at our local family shelter. This has become a yearly tradition” (Hensey, 2011). As related in the 2013 Annual Meeting, the church in Capetown, South Africa opened a chapel for all faiths, while Johannesburg runs a preschool in its church basement. As Director Michael Pabst(2013) remarked at the meeting, "People love to be helpful to the community".

Virginia Harris' brief 2003-2004 campaign to encourage members to emulate the Good Samaritan was of major importance and should be revived as a critical part of the healing outreach pursued by the present Board of Directors. Thus, the Christian Science movement would further shed its aloof persona and involve the membership in outreach.

\section{Conclusion}

The present direction of the movement since 2004 is exemplary in many ways, including the discarding of the imperial Mother Church, encouragement of members to come to their own conclusions about Church Manual provisions, a concentration on healing, a neglected hallmark of Christ Jesus' ministry. However, the Christian Science movement could be labeled as an "Eddy Healing Cult”, unless it expands its vision and field of operation. Perhaps this is not too jarring, since the early Christians were essentially a cooperative Jesus healing cult, but to stand the test of time, a religious group must grow out of its swaddling clothes - as the Latter Day Saints Church has successfully done, rather than reverting to its infancy.

Why are Scientists so dismissive about investigating why the movement grew and declined, plus giving due to the people who built the movement? Church records in Boston hold one key to reviving the movement. After all, the pioneer Christian Scientists in the United States were 45\% lower middle and working class and 17\% foreign born. That is, Christian Science originally appealed not to native-born, educated, affluent urbanites - as writers long assumed, but to a reasonably wide spectrum of American society.

Why is it wrong to spread the Christian Science gospel to large numbers of people who need it, without worrying if they would be $100 \%$ pure metaphysicians? Eddy herself notes that the "understanding, even in a degree, of the divine All-power destroys fear, and plants the feet in the true path...”. It is logical to assume that Eddy would find new ways of presenting CS in the present environment. One supposedly progressive member 
of a branch church exemplified the metaphysical myopia gripping the movement when she exclaimed, "If Mrs. Eddy were here, she would scurry about fixing the movement”. Why can’t Christian Scientists do it themselves? J. Thomas Black did observe, "So we feel that an increase in membership is a very natural thing, and we look to see that happen. We're expectant”.

The following 1979 pronouncement by the Board of Directors reveals the limitations under which the movement has operated for decades: "It is well to remember that our God-inspired Leader has left us all that we need for our individual and collective progress"(Christian Science Board of Directors, 1979). Something is terribly wrong if 1,500 branches of the 3,300 branches worldwide that existed have disbanded, a decline that only partially mirrors less extreme losses in the mainline churches. Given the large number of churches that have closed, coupled with low attendance at many remaining branches, the writer estimates that there are about 150,000 Christian Scientists remaining in the United States. By contrast, the other three American-born sects - Mormonism, Jehovah's Witnesses, and Seventh Day Adventists - have been growing exponentially, as have Pentacostals (Hartford Institute for Religious Research, 2012).

Excessive reverence for Eddy, earlier ill-advised actions and later laxness of the membership, rigid, unthinking mores and unenlightened interpretation of the Church Manual were major contributing factors in the atrophy and decline of the movement. One must also factor in profound medical advances during the past century, which have lessened the appeal of a church stressing physical healing. Christian Scientists must stop fawning over every dotted “i” and nuance in Eddy's writings and take the essence of her teachings into the larger world. Surely, more than a century after her passing, her movement needs to break new ground. Despite the rhetoric of the past 10 years, Harvard scholar Ann Braude is correct when she states that "things are very much focused internally" in the movement(Paulson, 2009).Timidity and fear of showing needed leadership must be cast out; altruism is needed, as illustrated by the following advice from the Apostle Paul: "Bear ye one another's burdens and so fulfill the law of Christ”.

The letter to the field just before the opening of the 2006 Annual Meeting in Boston proclaimed, "Mary Baker Eddy indicated that spiritual healing originally built the Christian Science movement. And there is every reason for us to assume that healing will rebuild it today"(Talbot, 2006). As this paper indicates, such an approach must take into consideration historical factors that facilitated the meteoric early growth of the movement. Simply trying to copy the past without understanding the historical context generally does not work. Further, in order to present Eddy's profound writings to a vastly changed world, the movement must strike out in bold new directions, instead of trying to mimic its origins.

Community outreach to all classes of people, not just pure metaphysics and healing individuals, is what will revive the movement. Consider the refreshingly different comments of newly-minted Director Robin Hoagland at the close of the 2013 Annual Meeting:

\footnotetext{
"If we're just focusing on individual healing, well-being and healing are important, but our roots are going to be too shallow. Roots going deeper into the healing of families, into the healing of communities and seeing how important spiritual healing is to the world, with roots like that there is no material limitation that is going to hold back the growth of this church" (Dunbar, p. 11).

Coupled with an appreciation of the workers who built the Christian Science movement, such an approach would reach "millions of unprejudiced minds - simple seekers of truth" and rebuild this American-based faith stronger than it ever was. Perhaps this is the harbinger of a form of "Christian Science social work", from
} 
which millions might benefit. If the Church of Christ, Scientist follows this path, it will disarm critics who label the movement as "ego-centric" and arm the membership to "Go ye into all the world...”(2014).

\section{References}

Albanese, Catherine L. (2007). A Republic of Mind and Spirit: A Cultural History of American Metaphysical Religion. New Haven: Yale University Press.

Annual Meeting (1973). Christian Science Journal 91(8). Retrieved from http://journal.christianscience.com/issues/1973/8/91-8/annual-meeting-1973

Braden, Charles. (1958). Christian Science Today: Power, Policy, Practice. Dallas. Southern Methodist University.

Center for Applied Research in the Apostolate (2013). Frequently Requested Church Statistics. Retrieved from http://cara.georgetown.edu/caraservices/requestedchurchstats.html

Christian Science Board of Directors (1979). From the Directors: Putting First Things First. Christian Science Sentinel, 81, 258.

Church Board Announces Changes (2004, December 7). Christian Science Monitor. Retrieved from http://www.lexisnexis.com/hottopics/lnacademic/?

Church Readers and the Manual (2009). Christian Science Journal, 127(2), 18-19.

Church Renewal (2010). Christian Science Journal 128(1), 14-15.

Clay, Jack (2009). A Church in Transition. Christian Science Journal, 127(1), 12-15.

Communion Service and Dedication. (1906). Boston Herald. In The First Church of Christ, Scientist and Miscellany. Boston

Curtis, Heather D. (2007). Faith in the Great physician: Suffering and Divine Healing in American Culture. Baltimore: Johns Hopkins University Press.

Driessen, Christine (2011). Christian Science. In John R. Peteet and Michael D’Ambra. The Soul of Medicine: Spiritual Perspectives and Clinical Practice. Baltimore: Johns Hopkins University Press.

Duin, Julia (2010, February 12). Just In: Latest Church Growth Statistics. Washington Times. Retrieved from http://www.washingtontimes.com/blog/belief-blog/2010/feb/12/latest-church-growth-stats-in/

Estes, Dorothy (2013) “Questions \& Answers.” Christian Science Journal 131(3), 43.

Fiske, Edward B. (1973, June 10). A Symbolic New Center for Christian Scientists. New York Times. Retrieved from http://search.proquest.com/hnpnewyorktimes/advanced?accountid=13379

From The Christian Science Board of Directors (2006). Christian Science Journal, 124(4), 61.

Gerard, Jeremy (1988, October 3). Christian Science Publisher Expands into TV and a Magazine. New York Times. Retrieved from http://search.proquest.com/hnpnewyorktimes/advanced?accountid=13379

Gottschalk, Stephen. (1973). The Emergence of Christian Science in American Religious Life. Berkeley: University of California Press.

Grimes, Paul. (2011) Questions. Christian Science Journal 129(10), 7.

Hartford Institute for Religious Research (2012). Fast Facts abput American Religion. Retrieved from Frequently Requested Church Statistics.

Hensey, Dorothy. (2011). “Budding Churches, Spreading Branches: A Church Grows in Port Townsend, Washington.” Christian Science Journal, 129 (12), 12.

Ivey, Paul. (1999). Prayers in Stone: Christian Science Architecture in the United States. Urbana, IL: University of Illinois Press.

Marlin, William. (1973). Formed Up in Faith: The Christian Science Center in Back Bay. Architectural Forum,139,24-39. Retrieved

from http://ehis.ebscohost.com/ehost/search/advanced?sid=becf4495-6feb-445e-8c72-82af370198a7\%40sessionmgr115\&vid=1\&h id $=116$

Mary Baker Eddy Library. (2009). Church Readers and the Manual. Christian Science Journal, 127(2).

Pabst, Michael. (2013) .Numbering the People -Desirable Benchmark or Misleading Distraction. Christian Science Journal 13(14), 51.

Paulson, Michael (2009). Church Struggles to Keep its Voice. Boston Globe. Retrieved from: http://christianscience.com/what-is-christian-science/a-closer-look-at-health/press-room-blog/church-struggles-to-keep-its-vo ice

Phinney, Allison W. (2011) Restoring Christian Healing in Contemporary Times. Christian Science Journal 129(12), 29-30.

Robert, Peel. (1966). Mary Baker Eddy: The Years of Discovery. New York: Holt, Rinehart, and Winston. 
Stark, Rodney. (1998). The Rise and Fall of Christian Science. Journal of Contemporary Religion 13(2), 189-214. Retrieved from http://www.jstor.org/

Swensen, Rolf. (1969). “The Seekers of the Light”: Christian Science in Oregon. M.A. thesis, University of Oregon.(1972). Special Collections on Christian Science in Oregon. PNLA Quarterly 37(4),15-16. (2003). Pilgrims at the Golden Gate: Christian Scientists on the Pacific Coast, 1880-1915. Pacific Historical Review 72(2), 229-263. Retrieved from http://www.jstor.org/stable/10.1525/phr.2003.72.2.229

Talbot, Nathan. (2006). Clerk’s Call to Annual Meeting June 2006. Christian Science Journal 124(5). Retrieved from ournal.christianscience.com/issues/2006/5/124-5/clerk-s-call-to-annual-meeting-june-2006

Tomlinson, Irving C. (1903). [Letter to Alfred Farlow]. Used by permission of the Mary Baker, Eddy Collection.

Trammel, Mary (2010). What Does It Mean to Give Your Whole Heart. Christian Science Journal, 128(2), pp.28-30.

U.S. Bureau of the Census. (1941). Religious Bodies, Vol (2). Washington, DC: United States Government Printing Office.

Von Fettweis Yvonne Cathe and Robert Townsend Warneck (1997). Mary Baker Eddy: Christian Healer. Boston. Christian Science Publishing Society.

Wolf, Judy. (2010). Spiritual Healing: The First Choice. Christian Science Journal 128(3), 28-31. 